\title{
Mapping vegetational and salinization phenomena to evaluate the extent of Lake Kelemenszék, Hungary
}

\author{
Brigitta Czauner, Judit Mádl-Szőnyi, \\ Department of General and Applied Geology \\ Eötvös Loránd University, Budapest
}

\author{
Anita Erőss, Anna Vojnits \\ Department of General and Applied Geology \\ Eötvös Loránd University, Budapest
}

\begin{abstract}
Lake Kelemenszék (Danube-Tisza Interfluve, Hungary) is a shallow saline lake which is fed, beside by precipitation, partly by meteoric and also by rising saline groundwater. The aim of the present study was to map the seasonally variable extent of the lake. The developed method is based on mapping of vegetational and soil salinization phenomena around the lake caused by discharging groundwater. It was found that an outer salty berm determines the maximum extent of the lake. Therefore, from the mapped maximum possible extent of the lake, from the lake-bed morphology and from the recorded lake water level, the actual lake extent and water amount can be deduced. Military and cadastral maps from the past 220 years and a satellite image were used to characterize the historical time variability of the lake extent. Additionally, an actual groundwater level map was compiled based on shallow well data. RMT sounding was carried out to evaluate the TDS content of the saturated near-surface sediments to examine the interaction between the lake and the canals around it.
\end{abstract}

Key words: mapping, lake extent, vegetation zone, salty berm, Lake Kelemenszék

\section{Introduction}

The aim of the present study was to map the seasonally variable extent of Lake Kelemenszék in the Danube-Tisza Interfluve (DTI). The lake developed within an up to $3 \mathrm{~km}$-wide topographic depression, with a 93-91 m ASL groundwater level elevation, as part of a chain of shallow $(30-80 \mathrm{~cm})$ saline lakes in the Danube Valley (Simon et al., this volume, Fig. 1). The lake receives water from precipitation as well as groundwater. Lake Kelemenszék is situated in a

Received: September 1, 2008; accepted: November 1, 2008 
"hydraulic window", which describes the discharge zone of the deep-origin saline water and fresh water infiltrated from the ridge region of the Danube-Tisza Interfluve (DTI) (Mádl-Szőnyi and Tóth 2009). It is endorheic because it has no natural surface discharge through a river or a channel. There are only three canals around the lake.

The Total Dissolved Solid content (TDS) of the lake is high $\left(8000-9200 \mathrm{mgL}^{-1}\right)$ due to evaporation, with significant $\mathrm{Na}^{+}\left(2100-2300 \mathrm{mgL}^{-1}, 97.71 \% \mathrm{e}\right)$ and $\mathrm{Cl}^{-}$ (1100-1300 $\mathrm{mgL}^{-1}, 38.44 \% \mathrm{e}$ ) proportion (Simon et al., this volume). Around the lake, halophytic vegetation, soil salinization and soil liquefaction can be identified (Mádlné Szőnyi et al. 2005).

The research was based on the mapping of vegetation and soil salinization phenomena around the lake, both of which are caused by groundwater discharge (Tóth 1999). The results of this mapping and some theoretical results of earlier studies (Meinzer 1923, 1960; Meyboom et al. 1966; Meyboom 1967; Várallyay 1967; Rajkai and Molnár 1981; Engelen and Kloosterman 1996; Klijn and Witte 1999) were used for the evaluation of the areal extent of the shallow lake. The mapping was carried out during a low-water stage in October 2006.

Additionally, to support and verify the results of mapping, further analyses were carried out with the use of geo-referenced archive maps to see how the extent of the lake could have changed over the past centuries. Furthermore, from the groundwater level mapping the actual lake-groundwater interaction could be evaluated. Radio-Magneto-Telluric (RMT) sounding was used to evaluate the TDS content of the saturated near-surface sediments, based on considerations of Simon et al. (this volume).

\section{Methods}

\section{Mapping vegetation and soil features}

The developed method for the survey was based on systematic mapping of observed vegetation and soil types' belts around the lake. These zones are located as follows: i) open water surface with almost $1 \mathrm{~cm}$ depth outside; ii) vegetation zones; and iii) salt-effected berms.

Water depth (almost $1 \mathrm{~cm}$ ) where the lake has an open water surface was identified systematically by GPS.

Two vegetation zones were distinguished around the lake: the first one was characterized by Bolboschoenus maritimus and the second one by Puccinellia limosa. The vegetation zones and salt-effected berms indicate the duration and depth of temporal water covering, soil moisture content and alkalinity of the water. These vegetation belts also connect to salt-effected berms. The Puccinellia limosa and the Bolboschoenus maritimus zones are divided by a so-called inner salty berm (Fig. 1; Fig. 2). The outer edge of the Puccinellia limosa zone is determined by the outer salty berm (Fig. 1; Fig. 3). 
Fig. 1

Theoretical zones and berms around the lake. 1. open water surface; 2. Bolboschoenus maritimus; 3. Puccinellia limosa; $4 . \sim 1 \mathrm{~cm}$ deep water; 5 . inner salty berm, 6 . outer salty berm
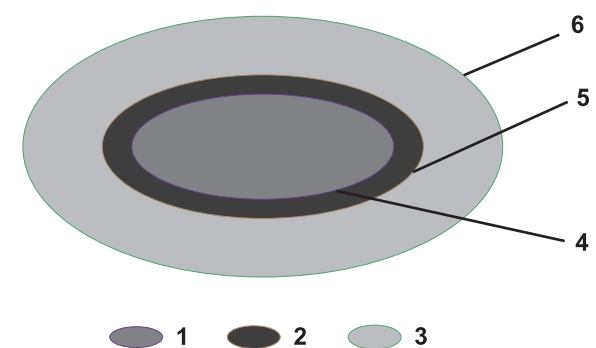

Fig. 2

Vegetation and soil salinization (inner salty berm) belts around the Lake (photo by B. Czauner)

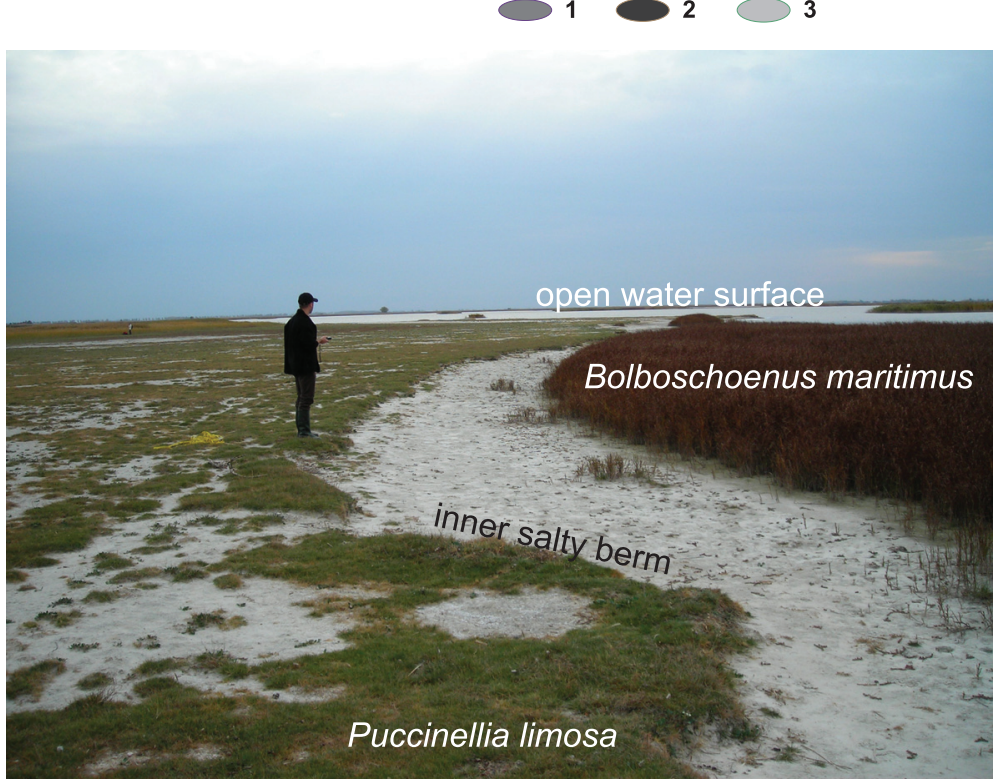

\section{Complementary methods}

The results of the lake's extent mapping were compared with the first (1783-1786), second (1857-1861) and third (1884) topographic surveys for military purposes (so-called military surveys) and cadastral maps, and a satellite image from 2002. The first cadastral map shows the quasi-natural conditions before regulating of the Danube River began in 1810. The second map indicates the impact of the river flood regulation of the Danube on the lake. The third map demonstrates the circumstances before inland water regulation between 1912 and 1929. Comparing the cadastral maps of the first, second and third military surveys the changes of the lake's extent during the last two centuries could be identified.

The actual interaction between Lake Kelemenszék and the groundwater was examined simultaneously by measuring the water level in 20 dug wells around 


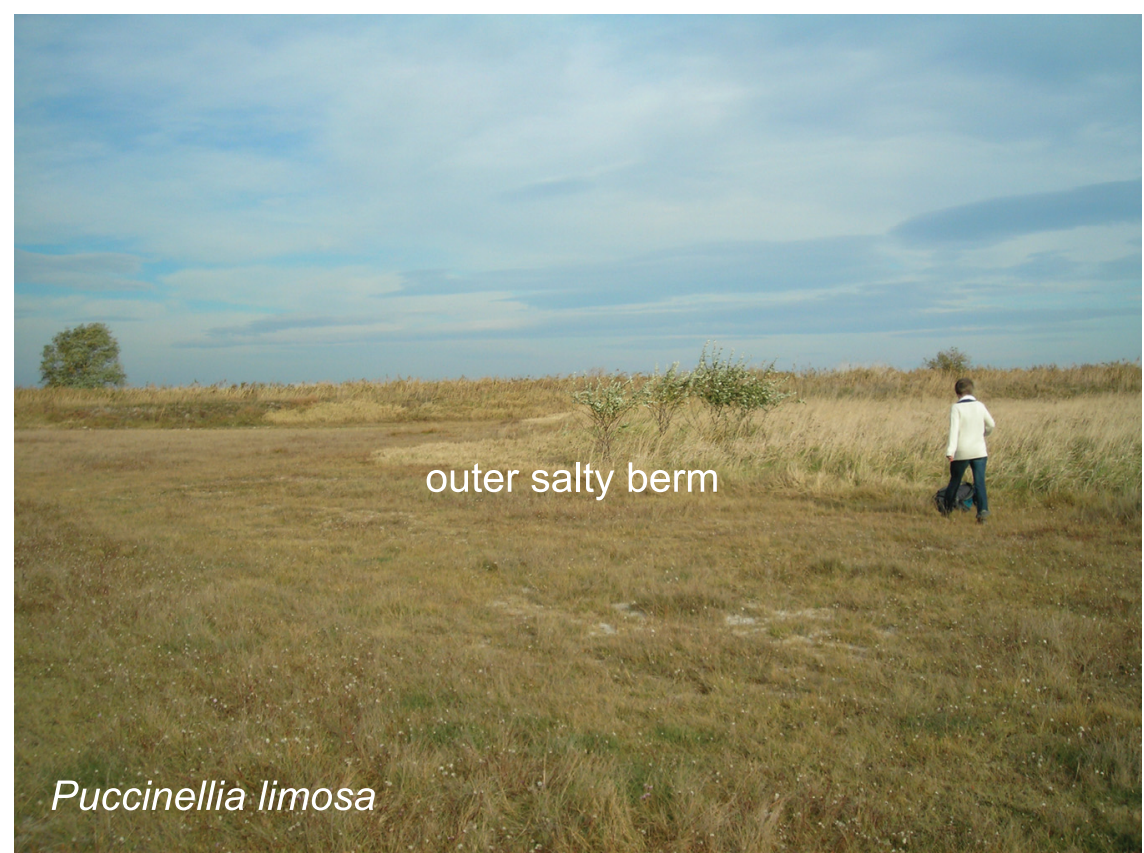

Fig. 3

Vegetation and soil salinization (outer salty berm) belts around the Lake (photo by B. Czauner)

the lake (see the locations of wells in Fig. 3. in Simon et al., this volume). If the groundwater level is higher, it means inflow to the lake takes place. In contrast the lower groundwater level means outflow from the lake (Sebestyén and Schneider 2001).

There are three fresh-water canals: the Danube Valley Canal east of the lake, the main Kiskunság Canal west of the lake, and the Kelemenszék Canal surrounding the northern side of the lake. These canals were built in the 1930s (Fig. 4). It was necessary to examine whether these canals could or could not influence the amount of lake water, its chemical composition and the vegetation around it. Theoretically artificial drainage can generate sub-local flow systems (Engelen and Kloosterman 1996).

The basis of the examination was the chemically different water of canals (TDS: $550 \mathrm{mgL}^{-1}$ ) and the groundwater (TDS: 3000-4000 mg L${ }^{-1}$ ) (Simon and Müller 2008; Simon et al., this volume, Fig. 8). The effect of fresh water recharge from the canal to the salty groundwater was controlled by Radio-Magneto-Telluric (RMT) measurements (after Turberg et al. 1994; Simon et al., this volume) along an E-W section across the lake and the main canals (Fig. 4). 


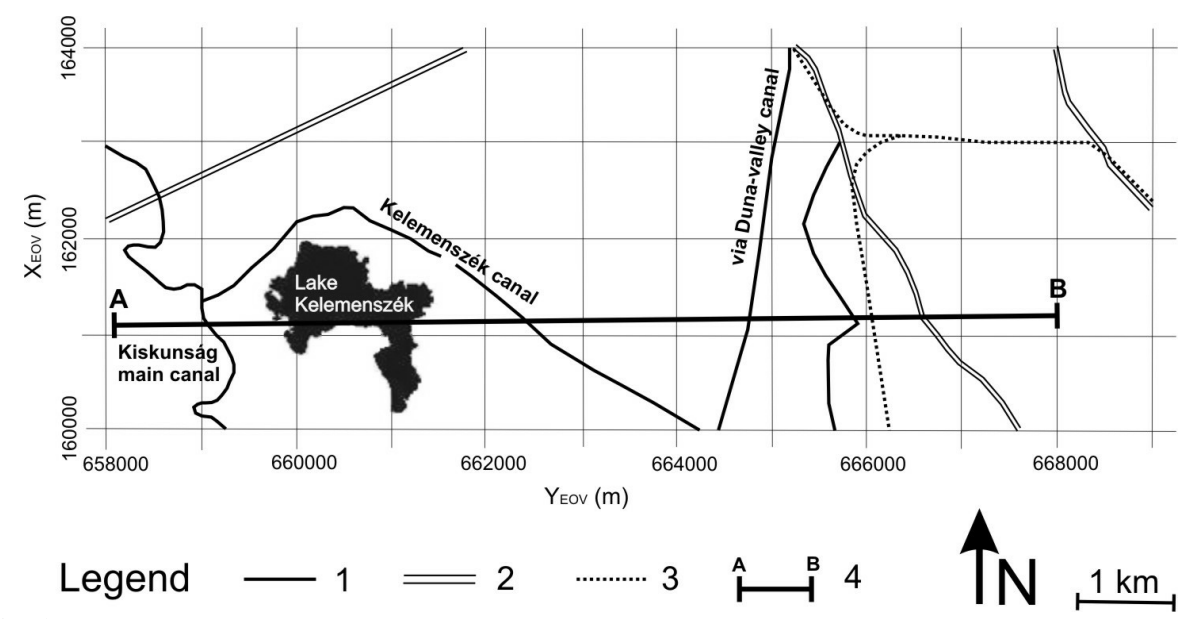

Fig. 4

Position of the canals surrounding the lake and the RMT-sounding section. 1. canals; 2. roads; 3. railway; 4 . line of the RMT section

\section{Results}

Mapping of the vegetation and the soil features

The location of the open-water surface, the different vegetation zones, and soil belts around Lake Kelemenszék (Fig. 5) were defined by a total of 2019 GPS points.

As a result of the mapping the extent $\left(2.05 \mathrm{~km}^{2}\right)$ and the water depth (30-80 $\mathrm{cm}$ ) of the lake could be approximated for the autumn of 2006. The inner berm (Fig. 5) is assumed to be the border of the lake during low-level periods. This low lake water situation was characteristic for the period of mapping.

On the other hand, the outer berm (Fig. 5) indicates the possible maximum extent of the lake $\left(3.15 \mathrm{~km}^{2}\right)$. It can be concluded that the vegetation zones are related to the flora's water requirements; it decreases from the central open water surface toward the marginal areas.

The distribution of different vegetation zones shows strong correlation with the morphology of the lake bottom. In spite of the many theoretical and practical uncertainties of the applied mapping methods, from the mapped maximum possible extent of the lake, from the lake-bed morphology and from the detected lake water level, the actual lake extent and water content can be deduced.

\section{Complementary methods}

Based on the comparison of the military and cadastral maps, the satellite image of 2002 and the October 2006 boundary contour of the lake (Fig. 6), it can be concluded that anthropogenic impacts, mainly the Danube river regulation have 


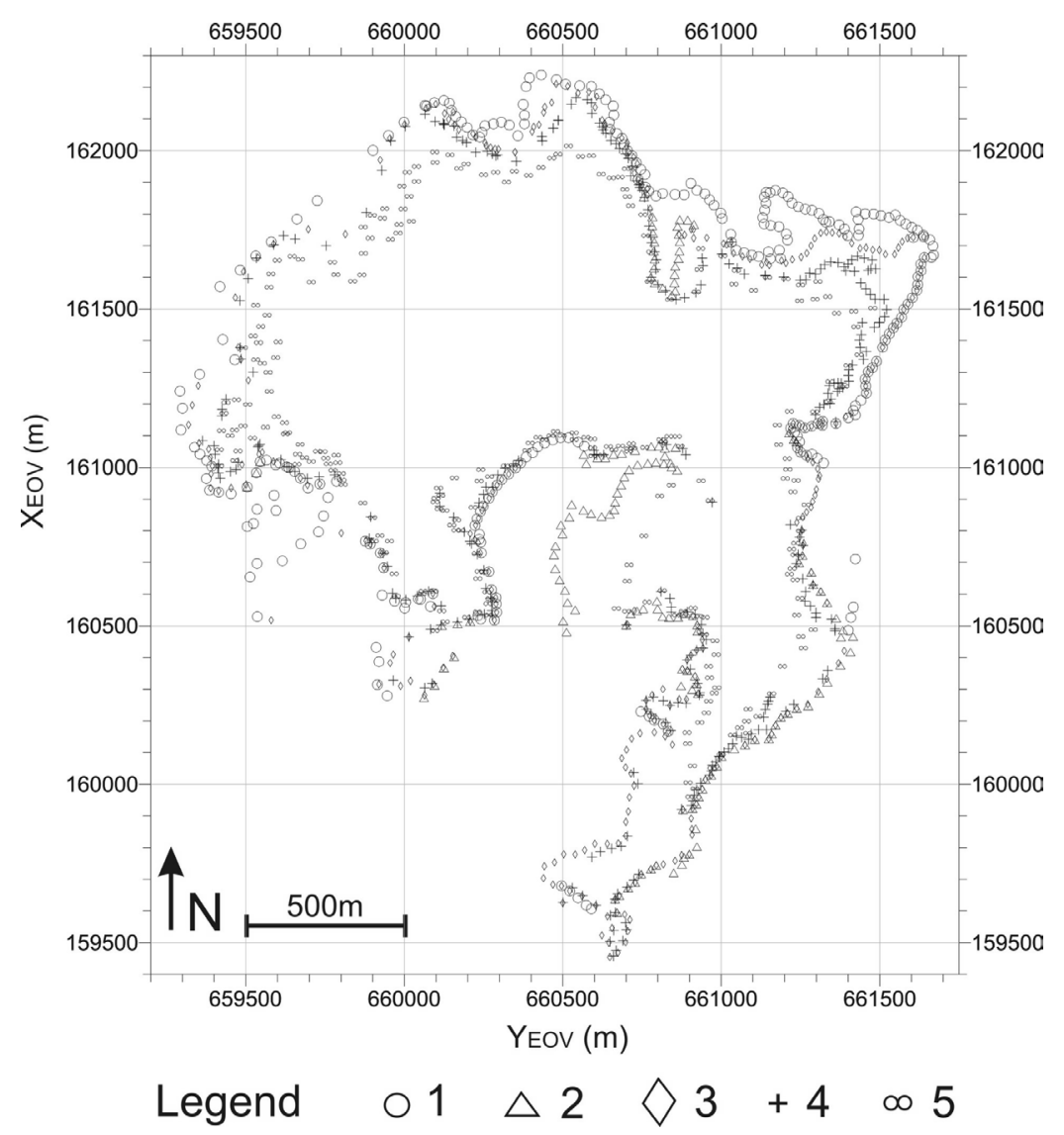

Fig. 5

Mapped zones around Lake Kelemenszék. 1. outer salty berm; 2. inner salty berm; 3. border of Bolboschoenus maritimus and Puccinellia limosa; $4 . \sim 1 \mathrm{~cm}$ deep water; 5 . open water surface

had an influence on the extent of the lake. Since the end of the 19th century, especially following the inland water regulating between 1912 and 1929, there has been no significant influence on the extent of the lake. This observation indicates a permanent recharge process of the lake, i.e. it has been fed mainly by groundwater discharge. According to the groundwater level map the lake is presently also fed by groundwater, because the lake level (90 m ASL) is lower than the groundwater level around the lake (>90 m ASL).

The measured data along the resistivity section (Fig. 4; Fig. 7) show the effect of saline groundwater discharge in the lake surroundings. The values increase from the west bank of the lake (min. 10-20 m) toward the eastern area (max. $70-95 \Omega \mathrm{m}$ ). The relatively high resistivity values $(40-65 \Omega \mathrm{m}) 2-3 \mathrm{~km}$ from the west shore of the lake indicate fresh water recharge to the groundwater from the main Kiskunság Canal. It can be concluded that recharge from the sub-local flow 

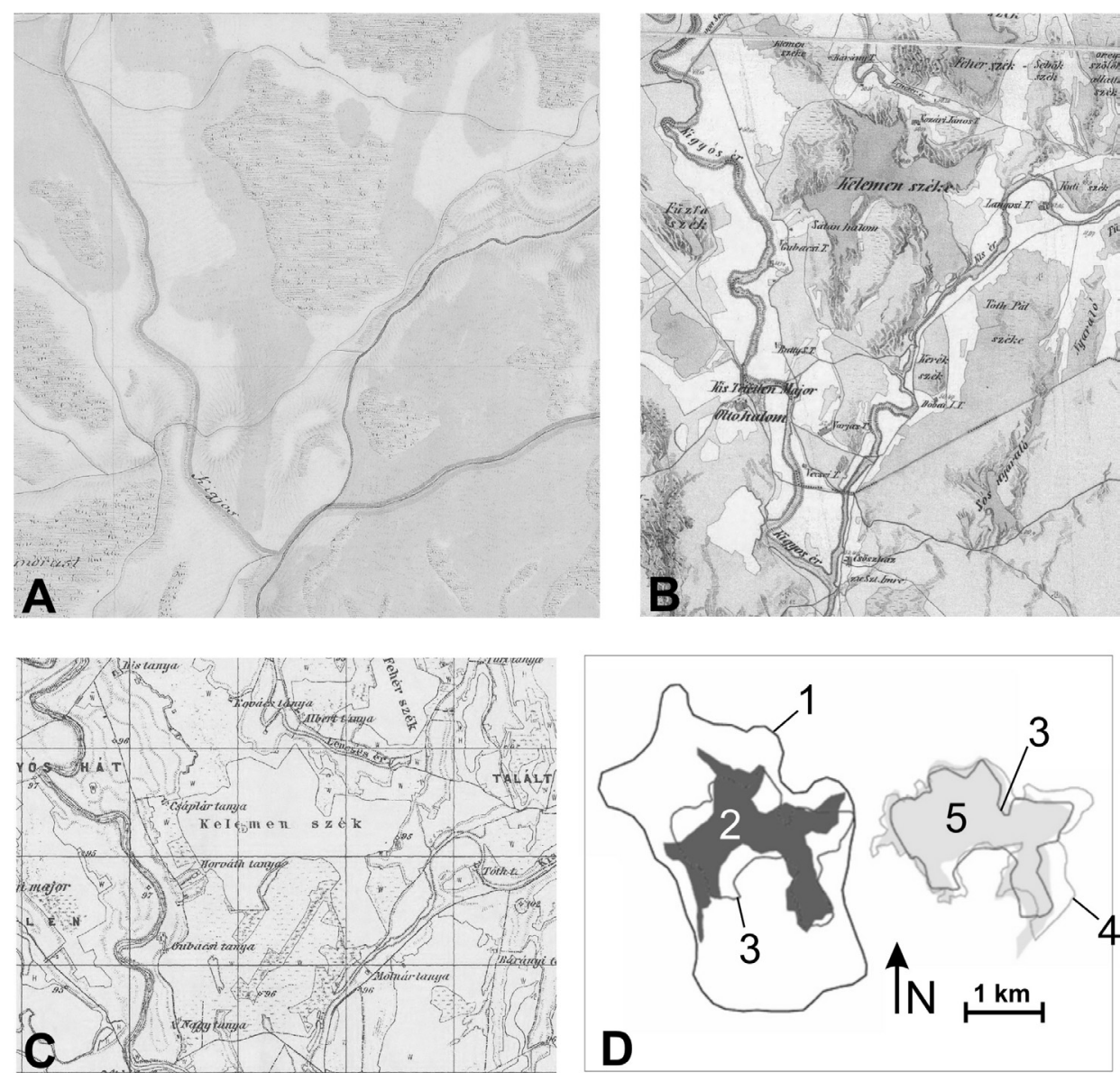

Fig. 6

Comparison of maps displaying the extent of Lake Kelemenszék. A) 1st military survey (1783-1786) (Arcanum 2006); B) 2nd military survey (1857-1861) (Timár et al. 2006); C) 3rd military survey (1884) (Biszak et al. 2007); D) Fluctuation of the open water surface extent of Lake Kelemenszék. 1. A; 2. B; 3. C; 4. satellite image (2002); 5. mapping survey (October 2006)

systems of the canals increases the resistivity of the saline water-saturated sediments (15-30 $\Omega \mathrm{m})$ and superimposes their own resistivity. The width of this freshwater sub-local recharge zone is not more than $500 \mathrm{~m}$ (Fig. 7).

According to the above-mentioned interpretation of the measured resistivity data the canals around the lake have no direct influence on the lake and the vegetation around it. 


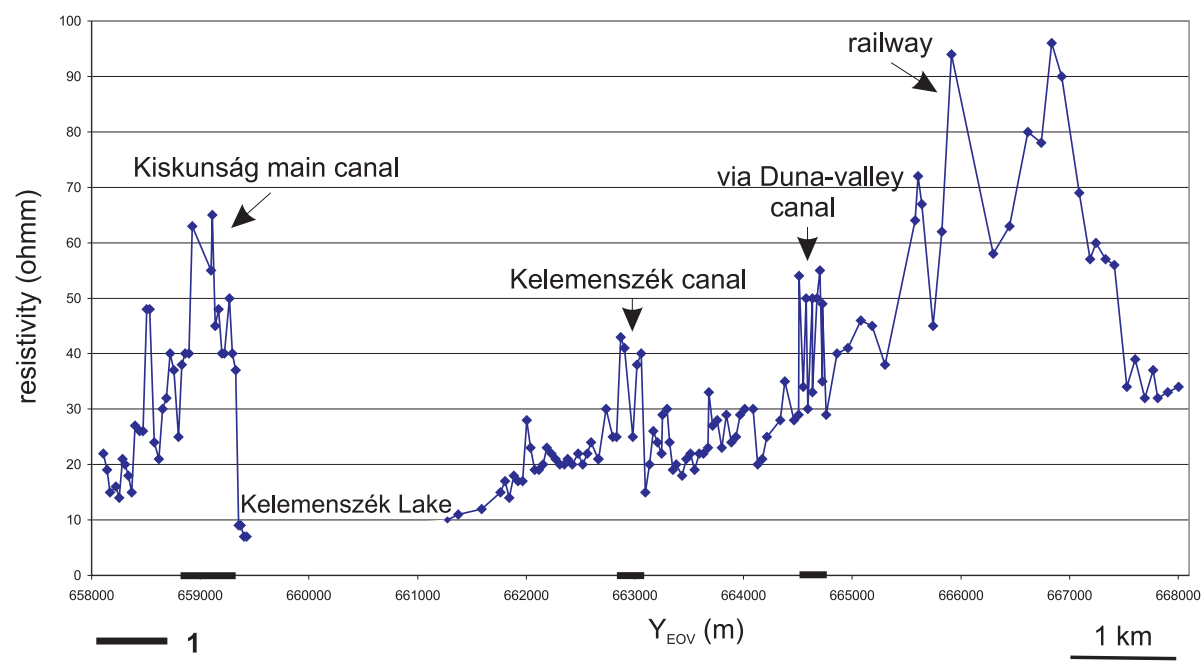

Fig. 7

RMT-resistivity section 1: recharge from the canal to the groundwater

\section{Conclusions}

A vegetation and soil-features mapping method was developed to determine the seasonally variable extent of the shallow saline Lake Kelemenszék. The lake is fed partly by precipitation and from fresh meteoric and also by rising saline groundwater. The method is based on mapping such phenomena around the lake which may indicate groundwater discharge.

It could be concluded that the inner salty berm is the border of the lake during the autumn low lake-level period and represents a $2.05 \mathrm{~km}^{2}$ areal lake extent. Otherwise the outer salty berm indicates the possible maximum extent of the lake $\left(3.15 \mathrm{~km}^{2}\right)$. The vegetation zones, with decreasing water requirement from the open water surface to the margins, show strong correlation with the morphology of the lake bottom.

As a result of the complementary analyses it was concluded that the extent of the lake has not changed dramatically, apart from the regulating of the Danube in the early 19th century. This indicates long-term stability of the lake water budget. The simultaneous groundwater-level mapping around the lake also indicates groundwater discharge into the lake. Interpretation of RMTmeasurements confirmed that the freshwater canals around the lake do not have direct influence on the amount of lake water and on the distribution of vegetation zones around it.

Comparing the mapped maximum extent of the lake, the lake bottom morphology and the registered lake water level, the actual extent of the lake can 
be inferred for any water stage. The results also give a basis for recording the seasonal, annual or even longer-term changes in vegetation. The established relationship between the vegetation zones and the lake extent can contribute to hydrological calculations (amount of water, etc.) and botanical research (seasonal, annual fluctuation of vegetation). It is hoped that this mapping method can also be applied to other shallow saline lakes in the Great Hungarian Plain.

\section{Acknowledgements}

This paper is based on the student scientific paper of Czauner et al. (2006). The authors gratefully acknowledge the assistance of Prof. J. Tóth, Prof. I. Müller, Sz. Simon, F. Zsemle and A. Erôss from the Department of Physical and Applied Geology. Prof. M. Szabó for her advice and for the review of the paper is also greatly appreciated. The research project was supported by the Hungarian National Science Foundation (T 047159) and by DATAQUA Electronic Ltd.

\section{References}

Arcanum 2006: Digitized maps of the Habsburg Empire. - The First Military Survey, Königreich Ungarn. DVD-publication, Arcanum, Budapest.

Biszak, S., G. Timár, G. Molnár, A. Jankó 2007: Digitized maps of the Habsburg Empire. - The third military survey, Ungarn, Siebenbürgen, Kroatien-Slawonien, 1867-1887, 1:25000. DVDpublication, Arcanum Adatbázis Kiadó, Budapest. ISBN 978-963-73-7454-8.

Czauner, B., Cs. Majercsik, A. Vojnits 2006: A Kelemenszék hidrogeológiai szempontú felmérése (Hydrogeological survey at Kelemenszék). - ELTE TTK Dept. of Applied and Environmental Geology, 50 p. (In Hungarian.)

Engelen, GB, F.H. Kloosterman 1996: Hydrogeological Systems Analysis. Methods and Applications. - Water Science and Technology Library, 20, Kluwer Academic Publishers, Dordrecht, Boston London.

Klijn, F., J.M. Witte 1999: Eco-hydrology: Groundwater flow and site factors in plant ecology. Hydrogeology Journal, 1, pp. 65-77.

Mádl-Szőnyi, J., J. Tóth 2009: A hydrogeological type section for the Duna-Tisza Interfluve, Hungary. - Hydrogeology Journal. DOI: 10.1007/s10040-008-0421-z.

Mádlné Szőnyi, J., Sz. Simon, J. Tóth, Gy. Pogácsás 2005: Felszíni és felszín alatti vizek kapcsolata a Duna-Tisza közi Kelemenszék és Kolon-tó esetében (Interrelationship between surface and subsurface waters at the Kelemenszék and Kolon Lakes, Danube-Tisza Interfluve, Hungary). Általános Földtani Szemle 30, pp. 93-110. (In Hungarian.)

Meinzer, O.E. 1923: (reprinted 1960) Outline of Ground-Water Hydrogeology. - Geological Survey Water-Supply Paper. United States Government Printing Office 494, pp. 1-71.

Meyboom, P. 1967: Mass-transfer studies to determine the groundwater regime of permanent lakes in hummocky moraine of Western Canada. - Journal of Hydrology, 5, pp. 117-142.

Meyboom, P., R.O. Everdingen, R.A. Freeze 1966: Patterns of groundwater flow in seven discharge areas in Saskatchewan and Manitoba. - Geological Survey of Canada Bulletin, 147, pp. 1-57.

Rajkai, K., E. Molnár 1981: Soil - water - plant relationships in a salt affected area of the Great Hungarian Plain. - Agrokémia és Talajtan, 30, pp. 97-104.

Sebestyén, S.D., R.L. Schneider 2001: Dynamic temporal patterns of nearshore seepage flux in a headwater Adirondack lake. - Journal of Hydrology, 247, pp. 137-150.

Simon, Sz. 2006: Aljzat eredetû sós vizek kimutatása hidraulikai és geofizikai módszerekkel Fülöpszállás szikvidékén, a Duna-Tisza közén (Determination of basinal origin saline waters 
240 B. Czauner et al.

with hydraulical and geophysical methods near to the salinized area of Fülöpszállás in the Danube-Tisza Interfluve). - Hidrológiai Tájékoztató, 1, pp. 53-54. (In Hungarian.)

Simon, Sz., I. Müller 2008: Near surface detection of depth-sourced saline water, Duna-Tisza Interfluve. - Georgikon for Agriculture, 11/1, pp. 1-18.

Timár, G., G. Molnár, B. Székely, S. Biszak, J. Varga, A. Jankó 2006: Digitized maps of the Habsburg Empire - The map sheets of the second military survey and their georeferenced version. Arcanum, Budapest, 59. (In Hungarian.)

Tóth, J. 1999: Ground water as a geologic agent. Theme Issue: - Hydrogeology Journal, 7/1, pp. 1-14.

Turberg, P., I. Müller, F. Flury 1994: Hydrogeological investigation of porous environments by Radio Magnetotelluric-Resistivity (RMT-R 12-240 kHz). - Journal of Applied Geophysics, 31, pp. 133-143.

Várallyay, Gy. 1967: Salt balance, salt equilibrium and salt accumulation processes in the soils of the Danube-valley. - Ph. D. thesis, Budapest. 